structure of the atom. Matter is heated, cooled, compressed under several thousand atmospheres, expanded, etc. The experiments shown on fluorescence and phosphorescence are as conclusive as they are beautiful. Last comes what is perhaps the most glorious chapter of modern science, the study of atomic particles and radiations. In this section are reproduced all the experiments which have marked a decisive step forward in the study of electrons, of $\mathrm{X}$-rays and the radiation of radioactive bodies, thus passing from the first Crookes tube to the artificial radio-elements and to the cosmic rays made visible thanks to the Wilson expansion chamber.

Four laboratories have been chosen by the chemists to show the history of their particular branch of science : an alchemist's laboratory, Lavoisier's laboratory, Berthelot's laboratory and finally a modern chemical laboratory. While further on, the 'elements' air, water and fire have a special room reserved for them. A great illuminated chart shows the periodic classification of the elements and an ingenious arrangement demonstrates the structure of all the atoms, from hydrogen to uranium. The principal analyses and syntheses are reproduced before the visitors' eyes, notably the separation of the gases of the air and the synthesis of acetylene in Berthelot's 'electric egg'. With regard to each of the important branches of this science-physical chemistry, inorganic chemistry, organic chemistry, metallurgical chemistry, photochemistry, geochemistry-it is possible to estimate how much the researches of pure science have contributed to the progress of industry (paper making, manufacture of sulphuric acid, preparation of colouring matters, dyeing and printing of materials, etc.).

Biology, as might be expected, shows here a living summary of the work of Pasteur together with an exhibit of the developments of microbiology-discoveries relating to smallpox, intestinal affections, cholera and typhus.

Medicine is divided into: (1) the diseases of nutrition, (2) cardio-vascular pathology, (3) medical physics, and (4) the history of medicine, in which special stress is laid on the fundamental part played by the discovery of auscultation. Also, for surgery, the considerable progress made in the last ten or twenty years is shown, more especially the influence of discoveries bearing on asepsis and anæsthesia. If anyone wishes to learn more about his own organism, and to know what his qualities are, both good and bad, he may take his place on the seat where the human machine is tested. There, after a series of tests, his biometric ticket will be made out and may prove useful in choosing a profession. If the results are good, he will be all the more surprised when confronted with the sensorial illusions shown in the section of psycho-physiology. Experimental biology demonstrates how living beings react to physical and chemical reagents. Plant physiology and biology are illustrated by dioramas, films and collec. tions. Finally, mention must be made of the section reserved for plant genetics, in which are exhibited the great facts of natural selection, of the formation of new species and of natural or induced changes.

Space will not permit the inclusion of the names of the many scientific men from France and abroad who have collaborated in the preparation of this great Exhibition. One exception must, however, be made in the case of the president, M. Jean Perrin. This Palace is the fruit of his untiring labours, and it is thanks to him also that France will soon possess a permanent Palace of Discovery.

It is only natural that in an exhibition representing the arts and technical sciences in modern life, scientific discovery should have its rightful place as the foundation of all progress. The Palace of Discovery brings this home to the general public and also shows the real beauty of science. Possibly, on leaving, the visitor will realize the truth of these words taken from Henri Poincaré's "Dernières Pensées": "Celui qui aura goûté à la Science, qui aura vu, ne fût-ce que de loin la splendide harmonie des lois naturelles, sera mieux disposé qu'un autre à faire peu de cas de ses petits intérêts égoïstes; il aura un idéal qu'il aimera mieux que lui-même et c'est là le seul terrain sur lequel on puisse bâtir une morale".

\title{
A Mesolithic Site in Brittany*
}

$\mathrm{T}$ HE Mesolithic site of Téviec, a rocky islet situated about eighteen hundred metres west of the shores of the peninsula of Quiberon in Brittany, which has been explored by M. and Mme. Péquart, is up to the present the most important station of this period that has been submitted to systematic and complete examination. Incidentally, it may be said, it gains in significance by the fact that examination of human skeletal remains from Téviec has elicited from MM. Boule and Vallois a detailed analysis of the physical characters of Mesolithic man, so far as known from the remains which have sur. vived, and a comparison of this race or type with those of the Upper Palæolithic.

The investigations leading to the discovery of the site were undertaken by $M$. and Mme. Péquart in the hope of throwing light on the domestic and tribal economy of the early inhabitants of Brittany,

* Téviec: station-nécropole mésolithique du Morbihan. Par Marth et Saint-Just Péquart, M. Boule et $\mathbf{H}$. Vallois. (Archives de l'Institut et Saint-Just Péquart, M. Boule et $H$. Vallois. (Archives de l'Institut
de paléontologie humaine, Mémoire 18.) Pp. ii $+227+19$ plates. (Paris: Masson et Cie., 1937.) 220 francs. which had been neglected by archæologists owing to their preoccupation with the all-absorbing study of the monuments of the country. For this purpose they were convinced that there was little hope of obtaining undisturbed evidence on the mainland, and consequently directed their investigations to the numerous small islands which lie off the coast of the Morbihan. In 1926 they were attracted by the evidence of a kitchen-midden exposed by marine erosion on this barren rock-it is little more, its dimensions being only four hundred metres in its greatest length and two hundred metres at its greatest breadth, while its elevation over the greater part of its extent is no more than ten metres-and began its excavation in July, 1928. After twenty-one days' excavation they were rewarded by the discovery of the first burial. The work of excavation was continued in 1929 and 1930 .

The island is completely barren, and even with the resources of modern civilization the excavating party found difficulty in keeping themselves provisioned 
during their stay on the island. There is, however, reason to believe that at the period of occupation under investigation the island was joined to the mainland, and the mode of life of the in habitants was riverine, rather than marine. This view is supported by the character of the charcoal, of which an abundance was found. This is the produce of forest trees. The animal remains are also those of a forest fauna. The inhabitants, however, do not appear to have subsisted to any great extent by either fishing or hunting, and their diet was almost exclusively of shell-fish. There is no supply of fresh water on the island.

It was largely this difficulty of making any prolonged stay on the island that was responsible for the fact that it had not been explored archæologically. The site was actually first discovered by $M$. F. Gaillard in 1883 , but he was able to do no more than make a few sondages on the north-west of the island. This brought to light some fragmentary evidence of a cooking-place and gave an approximation of the extent of the kitchen-midden ; but the great antiquity of the site was not appreciated. The present explorers recognized by the quantity of culinary refuse, molluses, fish and game, the quantity of charcoal and the fragments of bone and stone, as well as of the finished implements of these materials, that they were dealing with a kitchen-midden, while the absence of pottery and polished stone as well as the Tardenoisian character of the industry, indicated a Mesolithic site, or to be more precise a site belonging to a phase of culture corresponding to the postAzilian Maglemose, Mullerup, or Mugem.

The station covers a superficial area of about two hundred metres square, though without doubt originally it was much larger. Much of it has disappeared by marine erosion. The archæological bed runs to a depth of from $0.60 \mathrm{~m}$. to $1 \mathrm{~m}$. and is entirely homogeneous throughout its depth in composition and contents. It is composed of a black earth, heavily loaded with carbon, indurated, but breaking up readily, owing to the mass of organic material, bones and artefacts, it contains. The artefacts are homogeneous in character throughout. The site was, in the words of the authors, "vierge de tout remaniement".

A number of hearths and burials were found, constituting in all " 18 monuments". The burials were of twenty-three individuals, male and female, adult, adolescent and infant. In several instances infants were found buried with adults, for reasons that are not apparent. It is not invariably the burial of mother and child. In one grave the adult was male. Provision was made for the after-life in the form of implements and ornaments, especially neck. laces of shells, placed with the body. There appears to be a ceremonial use of deerhorn, possibly as a mark of a special position in the tribe, which recalls the magical significance of horns in Palæolithic art, as well as possibly being an anticipation of later belief.

The hearths which were found appear to fall into different categories. They are classified by the authors as domestic hearths, which show heavy and protracted use in the calcining of the stones used, cooking hearths, possibly set up for funerary feasts, and ritual hearths for sacrificial meals, which do not show the same signs of protracted use.

The burials are partly in the soil and partly covered by the kitchen-midden material. They show no signs of orientation. The bodies are disposed in a sitting position, with the legs forcibly flexed and the back against the wall, or else laid on the back, with head and shoulders raised, and the legs flexed, or sometimes crossed on the stomach.

The station is not in reality rich in industries of either bone or stone. Stone artefacts fall into three categories-small implements of geometric outline, finely and carefully worked, flakes retouched over part or the whole of their outline, and a group of specimens of larger size, bolder flaking, comprise nuclei, scrapers and thick flaked tools of various types, in which the fracture seems crude, rather than purposively directed. The bone objects include handles of deerhorn, polishers, objects of indeterminate use made from the tusk of a boar which may have been for piercing leather, and various points, of which one form, a "stiletto" (though only $15-17 \mathrm{~cm}$. long) appears to be accorded a special position in certain burials. Several objects show a simple attempt at decorative art in the form of engraved parallel diagonal or vertical lines. There is no evidence what. ever of anything in the nature of permanent structures for habitation.

This discovery of a Mesolithic habitation-necropolis has for prehistoric studies, and for the study of the Mesolithic in particular, a triple interest. It shows for the first time in the prehistory of Brittany a homogeneous and sealed station in the Morbihan of civilization of a people anterior to the builders of the megaliths, and proves, what had previously been denied, that Brittany was inhabited before the Neolithic age. In regard to French prehistory, Téviec may be regarded as the type station of the French Mesolithic, and in fact it is the first to furmish in abundance for France evidence relating to the fauna, flora and industries of that period, while it is the only station which has yielded such an abundance of material for the study of the physical characters of the peoples of Mesolithic age. Further, it throws a flood of light on their culture and beliefs. Finally, in relation to prehistory in general, it makes an important addition to knowledge of the distribution in Europe of Mesolithic culture and a link between the stations of the north of Europe and the south.

While it is clear that this Mesolithic civilization has no relation with the Neolithic of Brittany, there is no indication of its origin. Like the Mesolithic elsewhere, it shows certain features reminiscent of Palæolithic culture, and it may be that it is a descendant of a Palæolithic of Brittany as yet unknown.

The physical characters of the inhabitants of the site may be summarized as follows, although this affords only a very inadequate idea of the carefully detailed examination of the skeletal material which has been made by MM. Boule and Vallois.

From the twenty-three burials, twenty-one skeletons were obtained in such a state of preservation as to afford material for observation and study. In general terms, the subjects were not of an advanced age, and there was none who could be described as elderly. Of two very young individuals a few teeth only were obtained. Of the remaining twenty-one, six were infants and six only were truly adult, five ranging in age between twenty and twenty-five years. The sex was easily determined, as in all but one instance the difference between male and female was stongly marked. Out of fourteen individuals six were male and eight were female. An indeterminate individual was probably male, though a low stature possibly indicates a female. 
The head measurements were : length, male, 180$190 \mathrm{~mm}$., female, 170-190.2 mm.; breadth, male, 129-143 mm., female, $133-142 \mathrm{~mm}$.; basi-bregmatic height, male, 128-150 mm., female, 129-142 mm.; capacity, male, 1,561 c.c., female, 1,548 e.c. ; cephalic index, male, mean, $74 \cdot 3$, female, $75 \cdot 1$. The skulls show a tendency to vary from a moderate dolichocephaly to mesocephaly, this tendency being more pronounced in the female.

In general character the skull is massive, but without marked prominences, thick, and relatively capacious. In form it is 'beloid'. It is high, especially in the men, and carinated with a pronounced median ridge. The forehead is broad and rounded, the glabella moderately developed. The face is large and low, euryprosopic, and mesognathous to prognathous. The mandibles are robust with a pronounced chin. The dentition is megadont. The teeth are remarkable as showing the first known example of caries, not previously recorded before Neolithic times. The stature is distinctly below medium. The forearm is relatively long. The lower limbs show marked platymeria, and the tibire are platycnemic. As a type, this population is well evolved.

MM. Boule and Vallois have also, as a basis of comparison, made a detailed survey of all the skeletal material of man surviving from the Mesolithic period. This they classify into five types-the Ofnet brachycephal, the dolichocophalic-mesocephals of Téviec, the Ofnet dolichocephals, the Mugem dolichocephals, and the Natufians of Palestine.

On the whole, the authors are inclined to the view that notwithstanding certain clearly marked differences there is a close resemblance between Téviec man and the Chancelade skull of the Upper Palæolithic. It is certainly closer than to Cro-Magnon man. Of the three possibilities that the type is new in western Europe, that it is a cross-breed, or that it is a variation from Chancelade which has been produced in the long interval of time which has elapsed between the occurrence of the two types, the authors incline to the last-named.

\section{The Electrotor Smoke and Dust Meter}

\begin{abstract}
A RECENT paper by Dr. S. C. Blacktin (J. Indus. Hygiene and Toxicol.) describes an instrument he has devised for measuring dust suspended in the air. It is of a new type, and in designing it he has attempted to "avoid extraneous mechanisms or electric batteries which mar convenience and portability". The instrument consists of a hand pump of 100 c.c. capacity which draws air through a number of small nozzles, causing it to impinge upon a disk of celluloid or ebonite which, during the impact of the air, is made to revolve by means of a coarsely screwed rod which engages a nut or suitable projection in a hollow piston rod. The revolution of the disk is said to electrify it by rubbing against insulating material. In operation, a clean disk is inserted in the cap and the pump handle is next withdrawn to its greatest extent, and the cap with its disk screwed into position. The pump handle is next pressed inwards, rotating and electrifying the disk and emptying the pump. The ingress port is now held in the dust or smoke dispersion to be determined and the pump handle is withdrawn to its greatest extent
\end{abstract}

with a steady pull. The air or gas entering the ingress holes against the electrified disk is said to deposit its particle content. The records obtained appear to be circular rings upon the record disk, and these are examined in the usual way under a suitable microscope.

In the paper the instrument is illustrated and described, but no data are given on its efficiency of operation. The apparatus is very simple and, provided it fulfils the function it is intended for, should be a useful addition to the methods available.

It is not easy to see how the construction described could be very effective in its operation; for example, it appears that the dust deposit takes place upon the surface of the disk which is being rubbed by rotation and electrified. Mechanically speaking, it cannot be easy to ensure a suitable rubbing pressure between the disk and the surface in contact with it, taking into account the clearances required in the bearings of the screw and such like. However, as stated already, no information is given on its actual use.

J. S. OwENS.

\section{Performance of Noise Meters in Terms of the Primary Standard}

D URING the past few years considerable progress has been made on the intricate subject of noise measurement and many experimental data are now available. A paper on this subject was read by B. G. Churcher and A. J. King to the Institution of Electrical Engineers early this year.

Since loudness is a sensation and not a physical magnitude, its definition and measurement involve subjective considerations such as the manner in which the sound is heard. Until recently these factors were not specified, and so the various types of port. able noise meters in use gave appreciably different indications for a given noise. The British Standard Institution (B.S.I.) has taken an important step in removing difficulties. It has published an authoritative glossary of acoustical terms and definitions (B.S.S. 661) to which most of the workers in Great Britain will conform. Loudness is defined as, "that subjective quality of a sound which, in general, increases regularly with the intensity within the limits of audibility". A natural loudness scale is one such that when the number of units on the scale is doubled the magnitude of the sensation experienced by normal listeners is doubled also. The expression 